\title{
DAŽNIAUSIOS MAISTO ALERGIJOS SUKELTOS VIRŠKINAMOJO TRAKTO LIGOS VAIKŲ AMŽIUJE: EOZINOFILINIS EZOFAGITAS IR ALERGINIS PROKTOKOLITAS. DIETOS SVARBA JŲ GYDYMUI
}

\author{
Monika Sasnauskaite் $\dot{1}^{1}$, Vilija Bubnaitien $\dot{e}^{2}$ \\ ${ }^{1}$ Lietuvos sveikatos mokslu universiteto Histologijos ir embriologijos katedra, \\ ${ }^{2}$ Lietuvos sveikatos mokslu universiteto Vaiku ligu klinika
}

Raktažodžiai: maisto alergija, eozinofilinis ezofagitas, alerginis proktokolitas, dieta, vaikai.

\begin{abstract}
Santrauka
Pasaulyje daugejja nuo imunoglobulino E nepriklausomos maisto alergijos atvejų, pasireiškiančių eozinofiliniu ezofagitu, alerginiu proktokolitu bei kitomis eozinofilinėmis virškinamojo trakto ligomis. Eozinofilinis ezofagitas gali būti nustatomas vaikams ir suaugusiesiems, o alerginis proktokolitas yra kūdikiams būdinga liga, dažniausiai išnykstanti iki vienerių metų. Klinikinius simptomus abiem atvejais sukelia vartojamuose maisto produktuose esantys antigenai, o motinos pienu maitinamiems kūdikiams - motinos vartojamo maisto alergenai, patekę ị kūdikio organizmą su pienu. Efektyviausias eozinofilinio ezofagito ir alerginio proktokolito gydymo pasirinkimas - dietos taikymas. Visi gydymo dieta variantai pagrịsti vienu principu - visiškai pašalinti alergeną iš vartojamų maisto produktų. Eozinofilinio ezofagito gydymui galimi trys dietos pasirinkimai: amino rūgščių, empirinè ir tikslinè eliminacinès, o sẻkmingam alerginio proktokolito gydymui dažniausiai užtenka empirinės eliminacinès dietos. Prieš pradedant taikyti gydymą dieta, svarbu išsiaiškinti visus veiksnius, galinčius turèti itakos efektyvumui ir parinkti kiekvienam pacientui labiausiai tinkamą metodą.
\end{abstract}

\section{Ivadas}

Pasaulio sveikatos organizacija maisto alergiją apibrèžia kaip nepageidaujamą reakciją i maistą, sukeltą imuninių mechanizmų. Dažniausiai maisto alergiją skatinantis produktas yra karvès pienas (toliau - KP), kuris simptomus gali sukelti iki 6 proc. populiacijos [1]. Maisto alergija skirstoma i 3 pagrindines grupes: sukeltą imunoglobulino E (toliau - IgE), arba ne IgE sukeltą maisto alergiją ir mišrų imuninès kilmès padidèjusį jautrumą maistui [2] (1 pav.). Didesnę atvejų dalị sudaro IgE sukelta maisto alergija, kurios simptomai greitai pastebimi, dažniausiai per 2 val. nuo alergizuojančio maisto patekimo ị organizmą, galinti sukelti anafilaksinę būklę. Ne IgE sukeltos maisto alergijos patofiziologinis mechanizmas mažiau išaiškintas, jame dalyvauja kiti, nei IgE elementai, dažniausiai - eozinofilai ir T limfocitai [3]. Lengviau atpažinti tuos maisto alergijos atvejus, kurie pasireiškia odoje ar kvèpavimo takuose matomais simptomais, tačiau jie gali pasireikšti ir ịvairiomis virškinamojo trakto ligomis, ypač esant ne IgE sukeltai ar mišriai maisto alergijai (4).

Pasaulyje daugèja ne IgE sukeltos maisto alergijos atveju, pasireiškiančiu eozinofiliniu ezofagitu (toliau - EoE), maisto baltymų sukeltu alerginiu proktokolitu (toliau - AP) bei kitomis eozinofilinèmis virškinamojo trakto ligomis [5]. EoE priskiriamas mišriam maisto alergijos tipui, jo atsiradimui svarbesnis specifinio IgG4 padidèjimas stemplès gleivinèje, o ne IgE sukeltos reakcijos, kaip manyta iki šiol [6]. AP atveju svarbiausi ne IgE lemiami imuniniai mechanizmai: jo patogenezèje dalyvauja CD8, TH2 ląstelès, eozinofilais infiltruojami visi gleivinès sluoksniai $[2,7]$. EoE metu pažeidimai nustatomi stempleje, o AP atveju uždegiminiai pakitimai randami riestineje ir tiesiojoje žarnose. Prioritetas gydant šias imuninès kilmès virškinamojo trakto ligas skiriamas dietoterapijai, o kiti gydymo metodai svarstomi negavus pakankamo atsako. Dietoterapijos principas - ligos simptomus sukeliančių maisto produktų išaiškinimas ir jų pašalinimas iš kasdienio maisto raciono. Daugelyje studiju įrodyta, jog laikantis paskirtos dietos, galima pasiekti histologinę ligos remisiją ir klinikiniai simptomai išnyksta.

Darbo tikslas - apžvelgti naujausią mokslinę literatūrą apie dažniausias maisto alergijos sukeliamas vaikų virškinamojo trakto ligas, jų diagnostikos ir gydymo ypatumus. Aptarti šių ligų nemedikamentinio gydymo - dietoterapijos galimybes vaikams; palyginti gydymo skirtingais dietos variantais efektyvumą. 
Tyrimo medžiaga ir metodai

Atlikta publikacijų ir tarptautinių rekomendacijų apžvalga bei analizė eozinofilinio ezofagito, alerginio proktokolito bei jų gydymo dieta vaikų amžiuje tema. Publikacijų paieška vykdyta duomenų bazėse PubMed, Cochrane, Lippincot Williams \& Wilkins, naudota Google Scholar paieškos sistema. Paieškai naudotos raktažodžiu kombinacijos: children and food allergy, gastrointestinal food allergy, eosinophilic esophagitis and diet therapy, allergic proctocolitis and diet therapy, itraukti straipsniai anglų kalba, kurie buvo publikuoti ne vèliau kaip $2020 \mathrm{~m}$. balandžio mèn. Iš viso kriterijus atitiko ir išanalizuotos 34 publikacijos. Šiame straipsnyje pateikiami apibendrinti atliktos analizès rezultatai ir jų aptarimas.

\section{Tyrimo rezultatai}

Eozinofilinis ezofagitas. EoE būdingas stemplès gleivinès uždegimas su eozinofilų infiltracija ir klinikiniai disfunkcijos simptomai [8]. EoE gali sirgti vaikai ir suaugusieji. Tai antra pagal dažnị lètinio ezofagito ir pagrindinè vaikų ir jaunimo disfagijos bei maisto strigimo priežastis [9]. $2019 \mathrm{~m}$. publikuotoje metaanalizejje pastebèta EoE atvejų dažnèjimo tendencija, ypač tarp vaiku [10]. Per 4 metų laikotarpi (2014 - $2018 \mathrm{~m}$.) vaikų susirgimų skaičius padidèjo nuo 19,1 iki 34,4 atv. 100 tūkst. gyventojų [10]. Nors šis augimas gali būti aiškinamas geresne EoE diagnostika, tačiau negalima atmesti ir padidejjusio patologijos dažnio $[8,10]$. EoE dažniausiai nesukelia sunkių sisteminių komplikacijų, tačiau ilgalaikè stemplès pažaida gali tureti neigiamų pasekmių sveikatai - vyresniems vaikams dideja stemplès striktūrų formavimosi ir maisto strigimo stemplèje rizika, jaunesniems mitybos nepakankamumo rizika [11].

EoE diagnozè patvirtinama remiantis klinikiniais simptomais ir stemplès endoskopiniais bei biopsineje medžiagoje randamais specifiniais histologiniais pakitimais [8]. EoE gali pasireikšti panašiais ị gastroezofaginio refliukso ligos (toliau - GERL) simptomais: vèmimu, disfagija, maisto strigimu [4]. Dažniausiai stebimi EoE endoskopiniai pakitimai yra linijinès vagos -48 proc.; stemplès žiedai -44 proc.; gleivinès blyškumas ar sumažejęęs kraujagyslinis tinklas -41 proc.; baltos plokštelès ar eksudatas - 27 proc.; erozinis ezofagitas - 17 proc.; stemplès striktūros - 21 proc.; sumažeję̨s stemplès spindis -9 proc. [12]. Svarbu paminèti, jog net 17 proc. pacientų gali būti nestebima jokių pakitimu, todèl būtina atlikti biopsiją net ir esant normaliam endoskopiniam vaizdui $[8,12]$. Tiriant histologiškai, randama $\geq 15$ eozinofilų didelio regèjimo lauke stemplès epitelyje, gali būti ląstelių hiperplazija, eozinofiliniai mikroabscesai bei poepitelinio jungiamojo audinio fibrozė ar spenelių pailgèjimas [8].

Gydant sergančiuosius EoE, siekiama sumažinti stemplès gleivinès uždegimą, visiškai panaikinti klinikinius simptomus ir ligos sukeltas komplikacijas, apsaugoti nuo galimų jatrogeninių ir kitų komplikacijų, išlaikyti ligą remisijos fazèje bei pagerinti gyvenimo kokybę $[11,13]$. Šiuo metu yra trys pagrindiniai EoE gydymo metodai: dietoterapija, farmakoterapija (vietiniai gliukokortikosteroidai (toliau - GKS), protonų siurblio inhibitoriai (toliau - PSI)) ir endoskopinis stemplès dilatavimas, taikomas tik esant fibrozei, neretai derinamas su gydymu vietiniais GKS ar PSI [5] (2 pav.). Dietoterapija yra ịprastinis pirmo pasirinkimo EoE gydymo būdas. Vietiniai GKS budezonidas ir flutikazonas - efektyviai sumažina klinikinius simptomus ir pagerina histologinị vaizdą. Jie gali būti vartojami klampaus tirpalo, putojančiu tablečių pavidalo ar dozuojami inhaliatoriumi [8]. PSI ne tik sumažina skrandžio rūgšties gamybą, bet turi ir priešuždegiminių savybių, galinčių palengvinti ligos eigą [8]. Nepasiekus

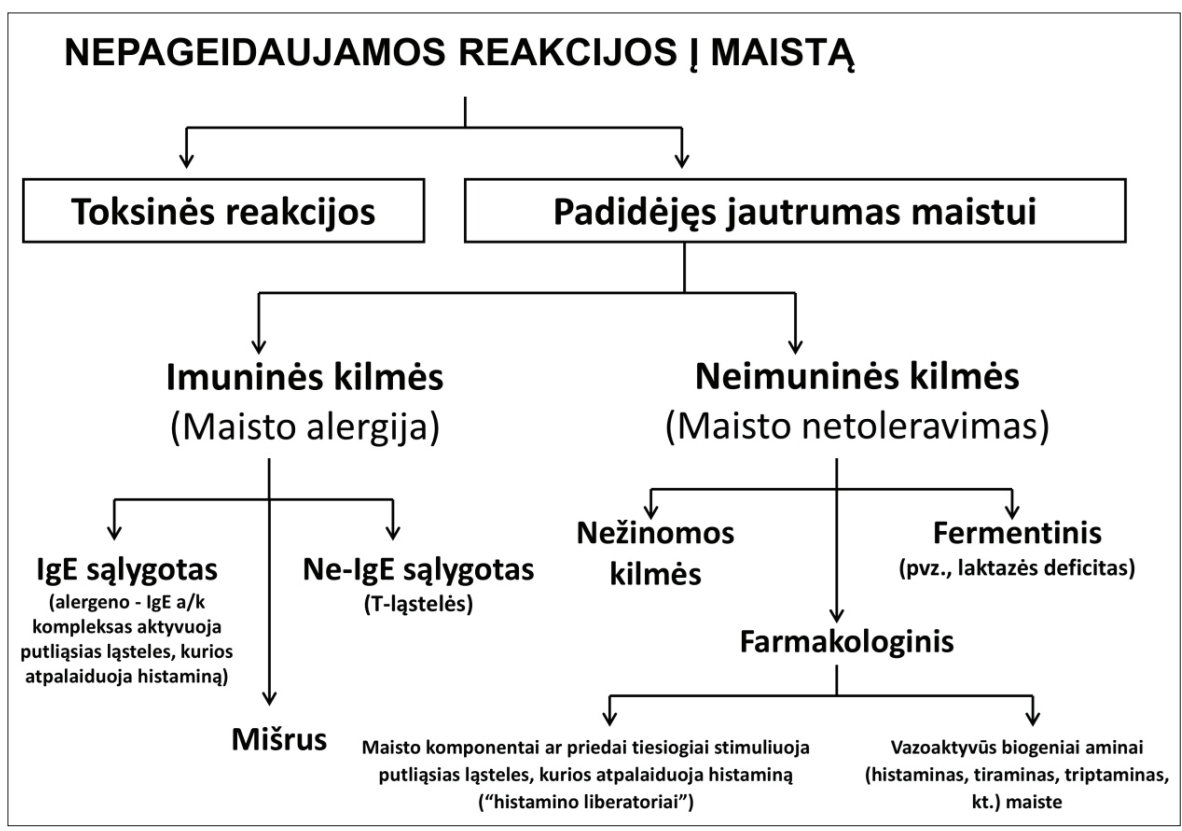

1 pav. Nepageidaujamų reakcijų i maistą klasifikacija

Adaptuota pagal Johansson SG et al. A revised nomenclature for allergy. An EAACI position statement from the EAACI nomenclature task force. Allergy 2001; 56(9): 813-824. 
histologinès remisijos, svarstomi kiti gydymo žingsniai [5].

Eozinofilinio ezofagito gydymas dieta. Dietoterapija yra efektyvus EoE gydymo metodas, ypač vaikams ir gerai motyvuotiems suaugusiesiems [11]. Tai vienintelis EoE gydymo metodas, tiesiogiai šalinantis ligos priežastị [14]. Gydymo dieta principas yra atrinkti ir neribotam laikui iš maisto sudèties pašalinti tuos maisto produktus, kurie provokuoja EoE paūmèjimą [6]. İrodyta, jog tai padeda pasiekti ilgalaikę klinikinę ir histologinę remisiją, net ir netaikant medikamentinio EoE gydymo [9].

Šiuo metu galimi trys pagrindiniai EoE gydymo dieta variantai: amino rūgščiu mišiniai, empirinè eliminacinè dieta ir tikslinè eliminacinè dieta pagal maisto alergenų testų rezultatus [6]. Pasirinkimas, kurį iš jų taikyti, priklauso nuo daugelio skirtingų veiksnių, tokių kaip vaiko amžius, esamosios mitybos problemos bei šeimos galimybès pritaikyti konkrečią dietą kasdieniame gyvenime [13]. A. Arias ir kt. metaanalizėje, kurioje didžiają dalį tiriamųjų sudarè vaikai, palygintas skirtingų dietos rūšių efektyvumas pagal histologinę remisiją. Nustatyta, jog amino rūgščių dietos efektyvumas buvo didžiausias ir siekè 90,8 proc., o eliminacinès dietos efektyvumas priklausė nuo konkretaus pasirinkimo: taikant 6 dažniausiai alergizuojančių maisto produktų dietą $-72,1$ proc., 4 produktų $-53,4$ proc., atsisakant tik KP $-68,2$ proc. Skiriant tikslinę dietą, efektyvumas buvo mažiausias $-45,5$ proc. [15]. Yra duomenų, kad dietos taikymas gali turèti neigiamos ịtakos pacientų ir jų šeimos narių gyvenimo kokybei. Apklausus EoE sergančius ir dieta gydomus vaikus nustatyta, jog pusè sergančiụjų dažnai jaučia susirūpinimą, pyktị ar liūdesị, kurie siejami su dietos keliamais apribojimais [16]. Vaikų globėjams dažnas vidutinis ar didelis stresas, kurị dažniausiai sukelia kai kurių maisto produktų paieška, jų paruošimas pagal vaiko dietos ypatumus, specialiojo maisto kainos ir skirtingi šeimos narių valgymo ịpročiai [16]. Visavertis dietos laikymasis gali kelti daug problemų pacientams ir jų šeimos nariams, todèl, siekiant geriausio rezultato, reikalingos gastroenterologo ir patyrusio dietologo konsultacijos bei jų bendradarbiavimas [8].

Prieš pasirenkant konkretų gydymo dieta variantą, visi metodai turètų būti detaliai aptarti su pacientu ir jo šeima, atkreipiant dėmesị ị anksčiau taikytas tikslines eliminacines dietas, paciento amžių, raidą, šeimos socialinę ir finansinę situaciją, galimas psicho-

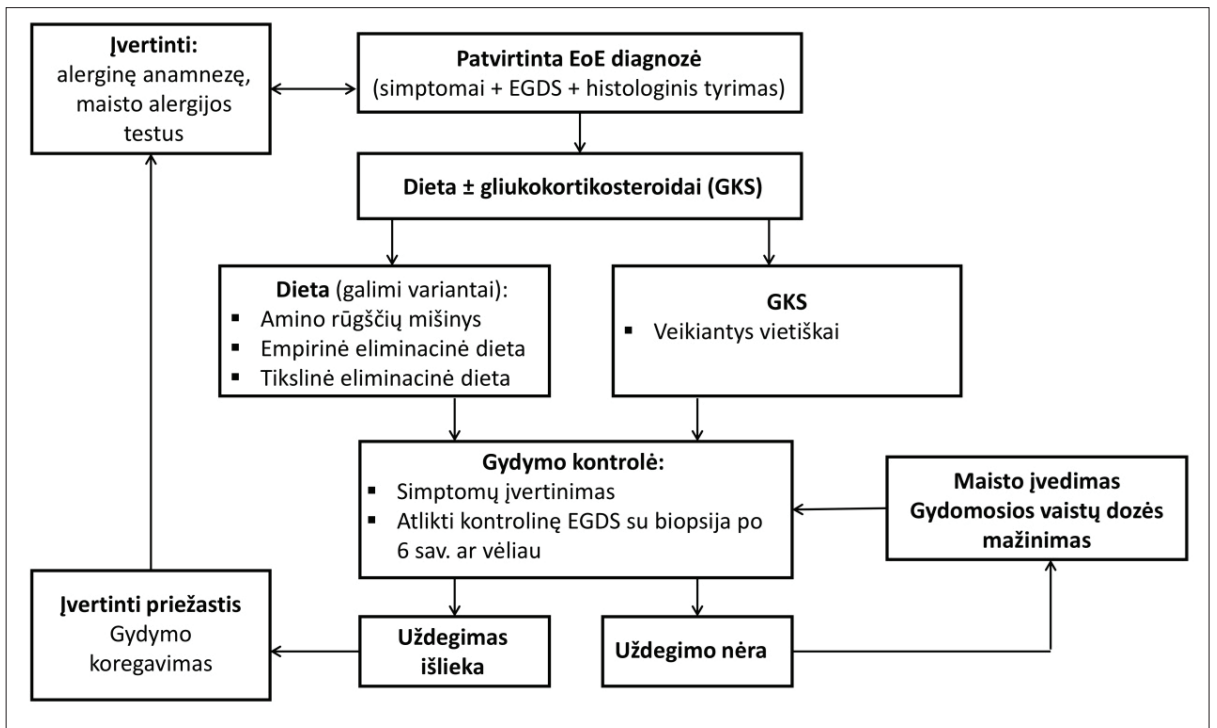

2 pav. Eozinofilinio ezofagito gydymo schema Parengta M. Sasnauskaités ir V. Bubnaitienès logines problemas, išsiaiškinti paciento ir jo šeimos prioritetus bei poreikius $[13,14]$.

Amino rūgščių mišiniai. Atliktos studijos rodo dideli amino rūgščių dietos efektyvumą, siekianti net 96 proc. [17]. Ši dieta yra vienas iš rezultatyviausių, o kartu ir vienas iš radikaliausių gydymo dieta pasirinkimų. Kuo labiau atsisakoma nuo viso baltymų turinčio maisto, o būtinaji azoto kiekị užtikrina specialios amino rūgštys, neturinčios antigeninių savybių [14]. Toks maistas dažnai yra nemalonaus skonio, dèl to ji skiriant vaikams neretai tenka naudoti nazogastrinius zondus [13]. Amino rūgščių dieta nepatogi dẻl daugelio socialinių, psichologinių ir gyvenimo kokybę bloginančių ypatumų [14], finansiškai brangi, tad gali sukelti šeimai finansinę ir socialinę naštą [13].

Empirinė eliminacinè dieta dažniausiai pasirenkama sergant EoE. Šios dietos, kuriose atsisakoma dažniausių EoE sukeliančių maisto produktu, jau beveik tapo standartu [6]. Tai kompleksinis metodas, aprepiantis tris pagrindinius etapus:

- pirmasis etapas - remisija. Ji pasiekiama ne anksčiau kaip po 6 sav., pašalinus iš maisto raciono visus pasirinktus produktus, išnykus klinikiniams simptomams ir histologiškai nustačius reikšmingą eozinofilų kiekio sumažejimą stemplès gleivinèje;

- antrasis etapas - maisto produktų grąžinimas. Pasiekus remisiją, ị kasdienị maisto racioną grąžinamas vienas iš tiriamujų maisto produktų. Po 6-8 sav. pakartotinai vertinami 


\section{2}

klinikiniai simptomai, atliekama kontrolinė endoskopija su biopsija, medžiaga tiriama histologiškai. Esant teigiamam atsakui, paeiliui grąžinamas vis kitas tiriamasis produktas ir kartojami tie patys žingsniai;

- trečiasis etapas - tolesnis dietos laikymasis. Galutinai ìvykdžius antraji etapą, iš kasdienio maisto raciono neribotam laikui pašalinami nustatyti EoE provokuojantys maisto produktai $[13,14]$.

Empirine eliminacinè dieta skirstoma ị grupes pagal iš kasdienès dietos pašalinamų produktų skaičių $-6,4,2$ ar 1 . Daugelyje tyrimų nustatyta, jog dažniausiai EoE paūmèjimą skatina šie 6 maisto produktai: KP, kiaušiniai, soja, kviečiai, žemès ir medžių riešutai, žuvis, jūros gèrybès $[6,14,18]$. Taikant empirinę 6 maisto produktų eliminacinę dietą (toliau -6 MPED) visi anksčiau išvardyti maisto produktai turi būti radikaliai pašalinami iš kasdienio maisto raciono [6]. Nustatyta, jog 6 MPED leidžia pasiekti histologinę remisiją iki 3/4 vaikų ir suaugusiujjų, sergančių EoE [9]. Jos efektyvumas mažesnis, nei amino rūgščių dietos, tačiau gali siekti net 81 procentą [17]. Skiriant 4 produktų empirinę eliminacinę dietą (toliau - 4 MPED), atsisakoma šių 4 maisto produktų: KP, kviečių, kiaušinių ir ankštinių daržovių [6]. A. Kagalwalla ir bendraautoriai aprašè tyrimą, kurio metu nustaté, jog po 8 savaičių 4 MPED taikymo, 64 proc. vaikų pasiekè histologinę remisiją, o klinikiniai simptomai visiškai išnyko 36 proc. tiriamujų [18]. Net ir galutinio teigiamo atsako nepasiekę vaikai jautè daugelio simptomų - krūtinès skausmo, ankstyvo sotumo jausmo ir pykinimo sumažejimą.

Vienas didžiausių eliminacinès dietos trūkumų yra silpna simptomų ir ligos aktyvumo koreliacija [13]. Net ir sumažèjus ar visiškai išnykus klinikiniams EoE simptomams, tiriamojoje stemplès medžiagoje vis tiek galima rasti gleivinès uždegimo požymių ir infiltraciją eozinofilais. Norint tiksliai ịvertinti organizmo atsaką i naują maisto produktą, neužtenka pasikliauti tik pagerejusia klinikine eiga, būtina atlikti stemplès endoskopinị tyrimą su biopsija. Kadangi didesnio maisto produktų kiekio eliminacinè dieta reikalauja ir didesnio kontrolinių endoskopijų skaičiaus, todèl dabar dažniau renkamasi 1-4, o ne 6-10 maisto produktų eliminacinè dieta [11]. Irodyta, jog didžiajai daliai (62 proc.) EoE paūmèjimą sukelia tik vienas maisto produktas [18], todèl manoma, jog net mažiau ribojančios dietos, kurių metu pašalinama mažiau maisto produktų ir atliekama mažiau endoskopinių tyrimų, gali užtikrinti panašų efektyvumą, kaip ir taikant 6 MPED, pastarają paliekant tik kaip rezervini gydymo variantą $[6,14]$. 2017 m. J. Molina-Infante ir kt. straipsnyje rekomenduojama gydymą pradèti empirine 2 (gyvulinès kilmès pieną ir gliuteno turinčius grūdus) arba 4 maisto produktus (gyvulinès kilmès pieną, gliuteno turinčius grūdus, kiaušinius, ankštines daržoves) ribojančia dieta, kuri taikoma bent 6 savaites [6].
Autoriai rekomenduoja pirmiausia bandyti i kasdienį maisto racioną grąžinti kviečius; neišryškejjus recidyvui, gerokai pagerinama gyvenimo kokybė ir sumažèja negalimų valgyti produktų skaičius. Tik nesant atsako ị šias pirmo pasirinkimo dietas, plečiamas pašalinamų maisto produktų spektras. Tokia pakopinès dietos („laiptelis aukštyn“ - „laiptelis žemyn“) taktika yra gana nauja ir reikalinga tolesnio efektyvumo ịvertinimo, tačiau įrodyta, kad taip gali būti ženkliai sumažintas atliekamų endoskopijų skaičius.

Karvès pieno empirinė eliminacinè dieta (toliau KPD) literatūroje dažnai išskiriama kaip atskiras pasirinkimas. Jis paremtas daugybės studijų rezultatais, kurie parodè, jog būtent KP yra dažniausiai EoE vaikams ir suaugusiesiems sukeliantis maisto produktas. Pienas didina EoE riziką 8 kartus ir gali EoE išprovokuoti 74 proc. vaikų [19]. Būtent dèl šios priežasties KPD yra vienas lengviausių būdų patikrinti organizmo atsaką ị dietos taikymą [6].Nustatyta, jog KPD ne tik reikšmingai sumažina eozinofilų skaičiu stemplès gleivinèje, tačiau mažina klinikinius simptomus bei gerina gyvenimo kokybę [20]. Kanadoje atliktame tyrime, kurio metu KPD skirta vaikams, kuriems neseniai buvo diagnozuotas EoE, bei neatsakiusiems ị gydymą PSI, simptomai sumažejo 90 proc., histologinę remisiją pavyko pasiekti 58 proc., o visišką remisiją - 23 proc. vaikų [21]. Lyginant griežtą dietą (atsisakoma visų pieno turinčių maisto produktų ir tų, kurių sudètyje pažymèta, jog galima rasti pieno produktų) su liberalia (leidžiami produktai, kuriuose yra pieno produktų ingredientų), pastaroji buvo mažiau efektyvi, tačiau skirtumas nebuvo statistiškai reikšmingas. A. Kagalwalla ir kt. studijoje KPD leido pasiekti histologinę remisiją net 65 proc. vaikų [22]. KPD galètų būti pirmo pasirinkimo dieta, ypač tiems pacientams, kurių šeimose sudètinga laikytis labiau ribojančios hipoalerginès dietos [20].

Tikslinė eliminacinė dieta. Individuali tikslinè eliminacine dieta sudaroma iš kasdienio raciono pašalinant tik tuos maisto produktus, kuriems nustatoma sensibilizacija, atlikus odos dūrio ir odos lopo méginius [6,14]. Daugelyje studijų stebèta, kad šiuo metu galimi sensibilizaciją maistui padedantys nustatyti odos ir kraujo testai nèra pakankamai tikslūs nustatyti EoE sukeliančius maisto produktus [14]. Vienoje iš jų, tik 32 proc. EoE pacientų nustatyta sensibilizacija maisto baltymams, remiantis specifinių IgE kraujyje testų rezultatais [21]. C. Henderson ir bendraautorių tyrime įrodyta, jog dieta pagal odos lopo ir dūrio mèginių rezultatus nebuvo efektyvesnè už 6 MPED [17]. Yra ir priešingus rezultatus nustačiusių studijų, kurių duomenimis tikslinė dieta efektyvumu prilygsta 6 MPED ir siekia 53 procentus [23]. Dèl dažnai pasitaikančių klaidingai teigiamų ir klaidingai neigiamų specifinių IgE kraujyje testų rezultatų, gydytojai dažniau renkasi empirinę eliminacinę dietą nei tikslinę [11]. 
Tolesnė EoE gydymo dieta taktika. Nustačius maisto produktus, provokuojančius EoE, rekomenduojamas ilgalaikis šių produktų pašalinimas iš kasdienès dietos, siekiant kuo ilgiau išlaikyti ligos remisiją ir sumažinti medikamentinio gydymo poreikị. Kadangi EoE yra neseniai išaiškinta liga, literatūroje trūksta studijų, vertinančių ilgalaikius gydymo dieta rezultatus [6].

Alerginis proktokolitas. AP yra labai dažna kūdikių maisto alergijos forma, kuri atsiranda pirmaisiais gyvenimo mènesiais ir dažniausiai išnyksta iki pirmujų gyvenimo metų pabaigos [7]. Nustatyta, jog ji net 78,6 proc. atvejų gali prasidèti iki 6 mẻnesių kūdikiams [24]. AP dažniausiai pažeidžia riestinę ir tiesiają žarnas [25]. Tikslus AP paplitimas pasaulyje nèra žinomas, o studijų nurodomi skaičiai pastebimai skiriasi, tačiau vienoje iš naujausiai atliktų studijų nurodyta, kad AP paplitimas siekia 17 procentų [26]. AP sergantiems kūdikiams būdingas protarpinis ar kasdienis tuštinimasis normalios ar skystesnès konsistencijos, putotomis, gleivingomis išmatomis su kraujo gyslelèmis ar krauju [25]. Iš gretutinių simptomų dažniausiai pasireiškia padidèjęs dujų išsiskyrimas (iki 30 proc.), protarpinis vėmimas (iki 27 proc.), pilvo skausmas (iki 20 proc.) [25]. Dažniausiai kūdikiai, sergantys AP, atrodo sveiki, tačiau kai kuriems iš jų gali prasidèti lengvo laipsnio anemija ar hipoalbuminemija. AP diagnozè patvirtinama remiantis klinikiniais simptomais ir esant teigiamam atsakui ị eliminacinę dietą, kuris anksčiausiai pastebimas po 72 val., atmetus kitas galimas hematochezijos priežastis [25]. Pasiekus ligos remisiją ir po 6 mèn. bandant pakartotinai skirti pašalintus iš maisto raciono produktus, kraujavimas dažniausiai vèl pasikartoja per 72 valandas. Greitų alerginių reakcijų testai nẻra informatyvūs AP diagnostikoje. Tuo tarpu uždelstų alerginių reakcijų nustatymas odos lopo méginių pagalba gali suteikti papildomos, gydymui svarbios informacijos, ypač sunkesniais ar ịprastam gydymui empirine eliminacine dieta nepasiduodančiais atvejais [29]. Diagnozuojant AP, storosios žarnos endoskopinis ir histologinis ištyrimas dažniausiai neatliekamas [28]. Invaziniai diagnostiniai tyrimai gali būti atliekami neaiškiais atvejais, ar nesant pakankamo atsako į gydymą. Kolonoskopijos metu dažniausiai nustatoma limfmazgių hiperplazija riestinejje ir tiesiojoje žarnose, pavienès erozijos. Tiriant medžiagą histologiškai, randama edema, epitelio ar poepitelinio jungiamojo audinio infiltracija eozinofilais (nuo 6 iki daugiau nei 15-20 eozinofilų didelio regèjimo lauke) [27,30].

Alerginio proktokolito gydymas dieta. Empirinè eliminacinè dieta yra pagrindinis AP sergančių kūdikių gydymo būdas [5]. Apie 60 proc. visų AP atvejų nustatomi krūtimi maitinamiems kūdikiams, kurių imuninis atsakas susiformuoja motinos vartojamame maiste esantiems alergenams, dažniausiai iš jų - KP; šiek tiek rečiau - kiaušiniams ir kukurūzų baltymams [25]. Didesnė AP rizika yra vien tik adaptuotais mišiniais (toliau - AM) maitinamiems kūdikiams, kuri gali sudaryti iki 50 procentu $[24,26]$. Šiems kūdikiams AP dažniausiai išprovokuoja ne tik KP, bet ir AM esantys sojos baltymai [25]. Sergant AP, empirinè eliminacinè dieta taikoma maitinančiai motinai arba vaikui, jei jis maitinamas AM [31]. A. Kaya ir kt. atliktame tyrime net 83,3 proc. kūdikių, kuriems išsivyste AP, buvo maitinami tik motinos pienu [30]. Nustatyta, jog visiems tiriamiesiems ligą provokavo KP ir didžiajai daliai (83,3 proc.) tai buvo vienintelis priežastinis maisto produktas. Pašalinus KP ir jo produktus iš motinos maisto raciono, kūdikiams kraujavimas iš tiesiosios žarnos išnyko, o išmatos visiškai normalizavosi per savaitę. Mažesnei daliai kūdikių, sergančių AP, iš dietos reikejjo pašalinti ir kiaušinius ( 6,6 proc.), vištieną ( 3,3 proc.), bulves (1,7 proc.), kviečius (1,7 proc.). $2020 \mathrm{~m}$. publikuotoje didelès imties studijoje KP buvo AP provokuojantis veiksnys 99,2 proc. kūdikių, o 24 proc. tiriamųjų nustatyta daugybinè maisto alergija [32]. Eliminacinès dietos efektyvumą įrodo ir V. Martin su bendraautoriais, aprašę tyrimą, kurio metu nustatyta, jog 47 proc. kūdikių AP simptomai išnyko iš motinos raciono pašalinus vien tik KP, 40 proc. $-\mathrm{KP}$ ir soją, o 13 proc. - KP, soją ir kiaušinius [26]. Daugelio studijų rezultatai rodo, jog kūdikiams, maitinamiems motinos pienu, iš jos raciono pašalinus $\mathrm{KP}$, bei kūdikiams, maitinamiems AM, pakeitus juos ị KP neturinčius, jau po 72 val. stebimas teigiamas rezultatas. Kai kuriems kūdikiams vien tik KP pašalinimo iš raciono gali nepakakti. Tokiais atvejais skiriami amino rūgščių mišiniai arba labai hidrolizuoti KP baltymų mišiniai [31]. S. Lucarelli ir kt. atliktame tyrime, kūdikiams, kuriems AP simptomai neišnyko motinai laikantis hipoalerginès dietos, buvo taikyta amino rūgščių dieta [29]. Skiriant amino rūgščių mišinius, šiems kūdikiams jau po 72 val. išnyko kraujavimas iš tiesiosios žarnos. Atlikus odos lopo mèginius, 50 proc. kūdikių stebètas dauginis įsijautrinimas maisto alergenams: KP -50 proc., sojai -28 proc., kiaušiniams - 21 proc., ryžiams - 14 proc., kviečiams -7 proc. Kitoje studijoje, tiriant kūdikiams taikomos dietos efektyvumą, 77,4 proc. kūdikių, kad pasiektų AP remisiją, pakako labai hidrolizuotų KP baltymų mišinių, o 22,6 proc. prireikè amino rūgčių mišinių [26].

Siekiant maksimalus AP gydymo rezultato, motinos turi būti tinkamai informuotos apie dietos principus ir griežtai jų laikytis. Irodyta, kad net smulkūs neatitikimai, tokie kaip vienkartinis sviesto panaudojimas, KP jautriems vaikams išprovokuoja kraujavimą iš storosios žarnos [27]. Po 6 mèn. dietą papildžius anksčiau pašalintais produktais, dažniausiai per 72 val. pasikartoja kraujavimas, kuris galutinai patvirtina AP diagnozę [25,27]. Daugumai vaikų visiška tolerancija AP sukeliantiems alergenams susiformuoja iki viene- 
rių, kai kurių autorių teigimu - iki trejų metų [26,27,31].

\section{Išvados}

1. EoE ir AP yra vienos dažniausių maisto alergijos sukeltų vaikų virškinamojo trakto ligų.

2. Vienas iš svarbiausių gydymo tikslų yra alergines reakcijas sukeliančio produkto išaiškinimas ir jo pašalinimas iš kasdienio maisto raciono.

3. Didžiausio efektyvumo galima pasiekti skiriant amino rūgščių dietą, tačiau dèl jos taikymo ypatybių (nemalonus mišinių skonis, didelè kaina, socialinès ir psichologinès problemos, susijusios su pacientu bei jo šeima) dažniausiai pasirenkamos empirinès eliminacinès dietos, kurių metu iš maisto raciono pašalinamas tik tam tikras maisto produktu skaičius.

4. Skiriant bet kurị gydymo dieta variantą, būtina griežtai jo laikytis, kad būtų ne tik pasiekta, bet ir sèkmingai išsaugoma ilgalaikè EoE ar AP remisija.

\section{Literatūra}

1. Nwaru BI, Hickstein L, Panesar SS et al. Prevalence of common food allergies in Europe: a systematic review and meta-analysis. Allergy 2014;69(8):992-1007.

https://doi.org/10.1111/all.12423

2. Yu W, Hussey Freeland DM, Nadeau KC. Food allergy: immune mechanisms, diagnosis and immunotherapy. Nat Rev Immunol 2016;16(12):751-65.

https://doi.org/10.1038/nri.2016.111

3. Cianferoni A, Spergel JM. Food allergy: review, classification and diagnosis. Allergology International 2009;58(4):457-66. https://doi.org/10.2332/allergolint.09-RAI-0138

4. Bischoff S, Crowe SE. Gastrointestinal food allergy: new insights into pathophysiology and clinical perspectives. Gastroenterology 2005;128(4):1089-113.

https://doi.org/10.1053/j.gastro.2004.08.015

5. Cianferoni A. Non-IgE mediated food allergy. Curr Pediatr Rev 2019.

https://doi.org/10.2174/1573396315666191031103714

6. Molina-Infante J, Gonzalez-Cordero PL, Arias A, et al. Update on dietary therapy for eosinophilic esophagitis in children and adults. Expert Review Gastroenterology Hepatology 2017;11(2): 115-23.

https://doi.org/10.1080/17474124.2017.1271324

7. Camargo LS, Silveira JAC, Taddei JAAC, et al. Proctocolite alérgica em lactentes: Análise da evolução do estado nutricional. Arq Gastroenterol. 2016;53(4):262-6. https://doi.org/10.1590/S0004-28032016000400010

8. Kumar S, Choi SS, Gupta SK. Eosinophilic esophagitis: current status and future directions. Pediatric Research 2020. https://doi.org/10.1038/s41390-020-0770-4
9. Lucendo AJ, Molina-Infante J, Arias Á, et al. Guidelines on eosinophilic esophagitis: evidence-based statements and recommendations for diagnosis and management in children and adults. United European Gastroenterology Journal 2017;5(3):335-58.

https://doi.org/10.1177/2050640616689525

10. Navarro P, Arias Á, Arias-González L, et al. Systematic review with meta-analysis: the growing incidence and prevalence of eosinophilic oesophagitis in children and adults in populationbased studies. Aliment Pharmacol Ther 2019;49(9):1116-25. https://doi.org/10.1111/apt.15231

11. Hirano I, Furuta GT. Approaches and challenges to management of pediatric and adult patients with eosinophilic esophagitis. Gastroenterology 2020;158(4):840-51.

https://doi.org/10.1053/j.gastro.2019.09.052

12. Kim HP, Vance RB, Shaheen NJ, et al. The prevalence and diagnostic utility of endoscopic features of eosinophilic esophagitis: a meta-analysis. Clin Gastroenterol Hepatol 2012;10(9):988-996.

https://doi.org/10.1016/j.cgh.2012.04.019

13. Kagalwalla AF. Dietary treatment of eosinophilic esophagitis in children. Dig Dis 2014;32(1-2):114-9.

https://doi.org/10.1159/000357086

14. Molina-Infante J, Lucendo AJ. Dietary therapy for eosinophilic esophagitis. J Allergy Clin Immunol 2018;142(1):41-7.

https://doi.org/10.1016/j.jaci.2018.02.028

15. Arias Á, González-Cervera J, Tenias JM, et al. Efficacy of dietary interventions for inducing histologic remission in patients with eosinophilic esophagitis: a systematic review and meta-analysis. Gastroenterology 2014;146:1639-48.

https://doi.org/10.1053/j.gastro.2014.02.006

16. Case C, Furuta GT, Atkins D, et al. Diet and stress in pediatric eosinophilic esophagitis. J Pediatr Gastroenterol Nutr 2017;65(3):281-4. https://doi.org/10.1097/MPG.0000000000001481

17. Henderson CJ, Abonia JP, King EC, et al. Comparative dietary therapy effectiveness in remission of pediatric eosinophilic esophagitis. J Allergy Clin Immunol 2012;129(6):1570-8. https://doi.org/10.1016/j.jaci.2012.03.023

18. Kagalwalla AF, Wechsler JB, Amsden K, et al. Efficacy of a 4-food elimination diet for children with eosinophilic esophagitis. Clin Gastroenterol Hepatol 2017;15(11):1698-707. https://doi.org/10.1016/j.cgh.2017.05.048

19. Kagalwalla AF, Shah A, Li BUK, et al. Identification of specific foods responsible for inflammation in children with eosinophilic esophagitis successfully treated with empiric elimination diet. J Pediatr Gastroenterol Nutr 2011;53(2):145-9. https://doi.org/10.1097/MPG.0b013e31821cf503

20. Kruszewski PG, Russo JM, Franciosi JP, et al. Prospective, comparative effectiveness trial of cow's milk elimination and swallowed fluticasone for pediatric eosinophilic esophagitis. 
Dis Esophagus 2016;29(4):377-84.

https://doi.org/10.1111/dote.12339

21. Teoh T, Mill C, Chan E, et al. Liberalized versus strict cow's milk elimination for the treatment of children with eosinophilic esophagitis. J Can Assoc Gastroenterol 2019;2(2):81-85. https://doi.org/10.1093/jcag/gwy030

22. Kagalwalla AF, Amsden K, Shah A, et al. Cow's milk elimination: a novel dietary approach to treat eosinophilic esophagitis. J Pediatr Gastroenterol Nutr 2012;55(6):711-6. https://doi.org/10.1097/MPG.0b013e318268da40

23. Spergel JM, Brown-Whitehorn TF, Cianferoni A, et al. Identification of causative foods in children with eosinophilic esophagitis treated with an elimination diet. J Allergy Clin Immunol 2012;130(2):461-7. https://doi.org/10.1016/j.jaci.2012.05.021

24. Lozinsky AC, Morais MB. Eosinophilic colitis in infants. J Pediatr (Rio J) 2014:90(1):16-21. https://doi.org/10.1016/j.jped.2013.03.024

25. Nowak-WeA. Food protein-induced enterocolitis syndrome and allergic proctocolitis. Allergy Asthma Proc 2015;36:172-84. https://doi.org/10.2500/aap.2015.36.3811

26. Martin VM, Virkud YV, Seay H, et al. Prospective assessment of pediatrician-diagnosed food protein-induced allergic proctocolitis by gross or occult blood. J Allergy Clin Immunol Pract 2020.

https://doi.org/10.1016/j.jaip.2019.12.029

27. Lake AM. Food-induced eosinophilic proctocolitis. J Pediatr Gastroenterol Nutr 2000; 30 Suppl:S58-60. https://doi.org/10.1097/00005176-200001001-00009

28. Nowak-Węgrzyn A, Katz Y, Mehr SS, et al. Non-IgE-mediated gastrointestinal food allergy. J Allergy Clin Immunol 2015;135(5):1114-24. https://doi.org/10.1016/j.jaci.2015.03.025

29. Lucarelli S, Di Nardo G, Lastrucci G, et al. Allergic proctocolitis refractory to maternal hypoallergenic diet in exclusively breast-fed infants: a clinical observation. BMC Gastroenterol 2011;11(1):82. https://doi.org/10.1186/1471-230X-11-82

30. Kaya A, Toyran M, Civelek E, et al. Characteristics and prognosis of allergic proctocolitis in infants. J Pediatr Gastroenterol Nutr 2015;61(1):1. https://doi.org/10.1097/MPG.0000000000000767

31. Nutr A, Dupont C. Allergic or pseudo-allergic gastrointestinal disorders food protein-induced enterocolitis syndrome and proctocolitis. Metab 2018;73:8-16.

https://doi.org/10.1159/000493671
32. Buyuktiryaki B, Celik IK, Erdem SB, et al. Risk factors influencing tolerance and clinical features of food protein induced allergic proctocolitis. J Pediatr Gastroenterol Nutr 2020. https://doi.org/10.1097/MPG.0000000000002629

33. Caubet JC, Szajewska H, Shamir R, et al. Non-IgE-mediated gastrointestinal food allergies in children. Pediatr Allergy Immunol 2017;28(1):6-17.

https://doi.org/10.1111/pai.12659

34. Gómez-Aldana A, Jaramillo-Santos M, Delgado A, et al. Eosinophilic esophagitis: current concepts in diagnosis and treatment. World J Gastroenterol 2019;25(32):4598-4613.

https://doi.org/10.3748/wjg.v25.i32.4598

\section{THE MOST COMMON GASTROINTESTINAL MANIFESTATIONS OF FOOD ALLERGIES IN CHILDREN: EOSINOPHILIC ESOPHAGITIS AND ALLERGIC PROCTOCOLITIS. THE IMPORTANCE OF DIET TREATMENT}

\section{Sasnauskaitė, V. Bubnaitienè}

Keywords: food allergy, eosinophilic esophagitis, allergic proctocolitis, diet therapy, children.

Summary: Number of cases of non-IgE-mediated food allergies, manifested by diseases of the gastrointestinal tract, such as eosinophilic esophagitis, allergic proctocolitis and other eosinophilic diseases of the gastrointestinal tract, is increasing. Allergic proctocolitis and eosinophilic esophagitis are the most common in childhood. The latter one can affect both children and adults whereas allergic proctocolitis is only diagnosed for infants and usually fully disappears until the age of 1 year. Various food antigens provoke symptoms of these diseases when they are digested. For breast-fed infants the disease is triggered by the antigens in maternal diet. Diet therapy is the first line treatment for both of these diseases. The main goal of diet treatment is to remove the specific food antigens from daily food intake. There are three diet choices for eosinophilic esophagitis treatment: elemental diet, empiric elimination diet and direct (food allergy skin testing-guided) elimination diet, whereas empiric elimination diet is usually enough for the successful treatment of allergic proctocolitis. It is important to evaluate any factors which can affect the efficacy of a diet treatment and choose the most suitable option for the patient.

Correspondence to: sasnauskaite.monika@gmail.com

Gauta 2020-04-18 